Jurnal Health Sains: p-ISSN: 2723-4339 e-ISSN: 2548-1398

Vol. 2, No. 6, Juni 2021

\title{
HUBUNGAN MEROKOK TERHADAP KEJADIAN HIPERTENSI DI KABUPATEN PIDIE JAYA
}

\author{
Nuriani, Kintoko Rochadi dan Fazidah Aguslina Siregar \\ Universitas Sumatera Utara, Medan, Indonesia \\ Email: nsnurianis.kep@gmail.com, kintokorochadi2@gmail.com dan fazidah65@yahoo.com
}

\begin{tabular}{l} 
ARTIKEL INFO \\
\hline Tanggal diterima: 5 Juni 2021 \\
Tanggal revisi: 15 Juni 2021 \\
Tanggal yang disetujui: 25 Juni \\
2021 \\
\hline
\end{tabular}

Keywords:

lifestyle; smoking; incidence of hypertension

\begin{abstract}
Lifestyle is one of the factor than can influence healthy living behavior. Hypertension is one of the non communicable diseases caused by lifestyle pattern, where hypertension is one of the disease than can trigger other diseases such as heart disease and stroke. The prevalence of hypertension in Aceh reached 27,8 percent in 2018 and the prevalence of hypertension in Pidie Jaya reached 23,4 percent in the same year. This study aims to determine the relation of smoking on the incident of hypertension in Kabupaten Pidie Jaya. This type of study was quantitative with analytic, research using crosssectional design. The sample are 270 samples obtained using multistage random sampling by combining three sampling techniques in stages. The instrument in this study was questionnaire. Data obtained in this study were analyzed by univariate and bivariate using simple logistic regression tests. The results showed that there were influences of smoking ( $p=0,002)$, long time smoking $(p=0.358)$ number of cigarattes $(p=0,931)$ on the incidence of hypertension. Meanwhile there is no relation of kind of coffee $(p=0,876)$. Health officer must active give health education and active establishing cooperation with community components as an effort to reduce the incidence of hypertension through campaigns against the danger of smoking.
\end{abstract}

\begin{abstract}
ABSTRAK
Pola gaya hidup adalah salah satu faktor yang dapat memengaruhi perilaku hidup sehat. Hipertensi merupakan salah satu penyakit tidak menular yang disebabkan oleh pola gaya hidup, dimana hipertensi adalah salah satu penyakit yang dapat memicu penyakit lainnya seperti penyakit jantung dan stroke. Prevalensi hipertensi di Aceh mencapai 27,8 persen di tahun 2018 dan prevalensi kejadian hipertensi di Kabupaten Pidie Jaya mencapai 23,4 persen di tahun yang sama. Penelitian ini bertujuan untuk mengetahui hubungan merokok terhadap kejadian hipertensi di Kabupaten Pidie Jaya. Jenis penelitian adalah kuantitatif analitik dengan desain cross sectional. Jumlah sampel sebanyak 270 diperoleh dengan menggunakan multistage random sampling. Data yang diperoleh dalam penelitian ini dianalisis dengan univariat, dan bivariat menggunakan uji regresi logistik sederhana. Hasil penelitian menunjukkan terdapat hubungan
\end{abstract}

\begin{tabular}{ll}
\hline How to cite: & Nuriari. et, al (2021) Hubungan Merokok terhadap Kejadian Hipertensi Di Kabupaten Pidie Jaya. \\
& Jurnal Health Sains 2(6). https://doi.org/10.46799/ihs.v2i6.191 \\
E-ISSN: & 2723-6927 \\
Published by: & Ridwan Institute
\end{tabular}


antara merokok $(\mathrm{p}=0,002)$, jumlah batang rokok $(\mathrm{p}=0,034)$, dan lama merokok $(\mathrm{p}=0,036)$ terhadap kejadian hipertensi namun tidak terdapat hubungan antara jenis rokok terhadap kejadian hipertensi. Petigas Kesehatan beroeran aktif dalam edukasi Kesehatan dan berperan aktif dalam menjalin

Kata Kunci:

gaya hidup; merokok; kejadian hipertensi
Kerjasama dengan komponen masyarakat dalam upaya mengurangi angka kejadian hipertensi melalui kampanye bahaya rokok.

\section{Pendahuluan}

Kematian akibat PTM secara mengalami peningkatan dari tahun $2010 \mathrm{ke}$ tahun 2020 yaitu sebesar 44 juta kematianatau 15 persen. Wilayah yang diprediksi memiliki angka kematian tertinggi di tahun 2020 adalah kawasan Asia Timur yaitu 10,4 juta serta Pasifik Barat yaitu 12,3 juta (Organization, 2018). Sedangkan di Indonesia sendiri peningkatan juga terjadi pada prevalensi PTM yaitu diantaranya kanker yaitu 1,8 persen, gagal ginjal yaitu 3,8 persen, diabetes yaitu 8,1 persen, stroke yaitu 10,9persen dan hipertensi yaitu 34,1 persen. Di Indonesia prevalensi hipertensi berdasarkan hasil pengukuran pada penduduk di usia 18 tahun sebesar 34,1 persen tertinggi di Kalimantan Selatan, sedangkan yang terendah di Papua sebesar 22,2 persen. Estimasi jumlahkasus hipertensi di Indonesia sebesar 63 juta orang sedangkan kematian di Indonesia akibat hipertensi sebesar 427.218 kematian atausebesar 6,7 persen (RI, 2016).

Di Aceh jumlah kasus untuk hipertensi pada tahun 2018 berjumlah 172.213 kasus sementara di Kabupaten Pidie jaya hipertensi merupakan urutan ke-6 dalam sepuluhpenyakit terbanyak dengan jumlah kasus ditahun 2018 sebanyak 4.190 kasus dan sebanyak 5.091 kasus di tahun 2019 (Mainaki, 2019).

Hipertensi terjadi disebabkan oleh berbagai faktor yang saling berpengaruh, secara patofisiologi faktor utama dari penyebab hipertensi antara lain adalah merokok. Banyaknya warung kopi di Aceh yang menyediakan kopi dengan berbagai cita rasa tidak terlepas dari kebiasaan merokok bagi para penikmat kopi. Penelitian terkait merokok yang mengakibatkan meningkatkan tekanan darah telah dilakukan diantaranya ditemukan adanya hubungan antara kebiasaan merokok dengan meningkatnya tekanan darah (P 0,000) dengan resiko (OR 6,75) (Elvivin et al., 2016). Penelitian yang dilakukan oleh (Firmansyah et al., 2019) di Palembang diperoleh bahwa kebiasaan merokok (P 0,014) memiliki hubungan signifikan terhadap terjadinya hipertensi.

Tingginya angka kejadian kasus hipertensi di Kabupaten Pidie Jaya salah satunya dipengaruhi perilaku kebiasaan minum kopi dan merokok maka peneliti ingin melakukan penelitian tentang pengaruh kebiasaan minum kopi dan merokok terhadap kejadian hipertensi di Kabupaten Pidie Jaya.

Tujuan penelitian ini adalah untuk mengetahui hubungan merokok terhadap kejadian hipertensi di Kabupaten Pidie Jaya.

\section{Metode Penelitian}

Jenis penelitian ini adalah penelitian kuantitatif dengan analitik dengan menggunakan metode pendekatan cross sectional. Penelitian ini di Kabupaten Pidie Jaya. Adapun pertimbangan dalam penentuan lokasi penelitian ini karena Kabupaten Pidie Jaya merupakan daerah nomor dua kasus tertinggi hipertensi dengan jumlah peserta 29.927 (17,21\%) (Pamaila, 2019).

Populasi dalam penelitian ini adalah masyarakat yang ada di Kabupaten Pidie Jaya yang berusia 20-70 tahun yakni sebanyak 89.753 orang. 
Pemilihan sampel menggunakan metode multistage random sampling, dimana teknik tersebut digunkan dikarenakan populasi penelitian yang cukup besar dan memiliki wilayah geografis yang cukup luas. Proses pengambilan sampel dilakukan secara acak yang dilakukan di setiap tahap yaitu pada gugus (cluster) dan unit sampling. Adapun tahapan dalam teknik pengambilan sampel yaitu:

Adapun wilayah yang menjadi penelitian adalah 3 wilayah puskesmas yakni Puskesmas Bandar Dua, Puskesmas Jangka Buya, dan Puskesmas Ulin. Pemilihan sampel masyarakat pada setiap wilayah kerja puskesmas menggunakan teknik simple random sampling. Jumlah sampel dalam penelitian ini adalah 270.

Penderita hipertensi adalah kejadian hipertensi adalah rata-rata tekanan darah sistolik dan diastolik responden yang diukur menggunakan alat spygmomanometer air raksa sebanyak dua kali dengan jarak pengukuran 5 menit yang dilakukan oleh tenaga medis.

Merokok adalah kebiasaan responden mengonsumsi rokok tiap harinya, yang didefenisikan sebagai responden yang memiliki kebiasaan merokok apabila secara rutin mengonsumsi rokok minimal satu batang per hari. Kebiasaan merokok dilihat berdasarkan lama merokok, jumlah rokok dan jenis rokok (Martiani \& Lelyana, 2012).

Lama merokok adalah rentang waktu responden mulai mengonsumsi rokok pertama kalinya hingga saat wawancara yang dikategorikan menjadi $<10$ tahun dan $\geq 10$ tahun.

Jumlah rokok adalah banyak rokok yang dikonsumsi responden dalam satu hari yang dikategorikan menjadi 1-10 batang/hari dan 11-20 batang/hari.

Jenis rokok adalah macam rokok yang dikonsumsi responden yang dikategorikan menjadi rokok biasa (rokok filter) dan rokok kretek (rokok non filter dengan kandungan utama tembakau dan cengkeh).

Data yang dikumpulkan dalam penelitian ini terdiri dari data primer dan data sekunder. Data primer adalah data yang diperoleh secara langsung dari sumber informasi dengan menggunakan instrument kuesioner dan wawancara. Sedangkan data sekunder diperoleh Dinas Kesehatan Aceh.

Setelah pengolahan data, tahap selanjutnya adalah menganalisa data dengan menggunakan aplikasi perangkat analisis statistik. Analisis yang dilakukan pada penelitian ini adalah analisis univariat.

\section{Hasil dan Pembahasan}

\section{A. Hasil Penelitian}

Analisis univariat dilakukan untuk melihat distribusi variabel yang ada pada penelitian ini. Variabel independen pada penelitian ini diantaranya berdasarkan karakteristik responden yaitu umur, jenis kelamin, riwayat penyakit hipertensi, dan merokok yang meliputi lama merokok. Jumlah batang rokok, dan jenis rokok.

\section{Karakteristik Responden}

Responden dalam penelitian ini berjumlah 270 orang. Karakteristik responden dalam penelitian ini adalah umur, jenis kelamin, dan riwayat penyakit hipertensi. Karakteristik responden dapat dilihat pada tabel berikut:

\section{Tabel 1}

Distribusi Responden Berdasarkan Karakteristik Responden

\begin{tabular}{lcc}
$\begin{array}{l}\text { Karakteristik } \\
\text { Responden }\end{array}$ & $\mathrm{n}$ & $\%$ \\
\cline { 1 - 1 } Umur & & \\
\hline 20-42 tahun & 136 & 50,4 \\
\hline 43-66 tahun & 134 & 49,6 \\
\hline Total & 270 & 100 \\
\hline Jenis Kelamin & & \\
\hline \multicolumn{1}{c}{ Laki-laki } & 249 & 92,2 \\
\hline \multicolumn{1}{c}{ Perempuan } & 21 & 7,8 \\
\hline Total & 270 & 100 \\
\hline $\begin{array}{l}\text { Karakteristik } \\
\text { Responden }\end{array}$ & & \\
\hline
\end{tabular}




\begin{tabular}{lcc}
\hline $\begin{array}{l}\text { Riwayat Penyakit } \\
\text { Hipertensi }\end{array}$ & 222 & 82,2 \\
\hline Ya & 48 & 17,8 \\
\hline Tidak & 270 & 100 \\
\hline Total & & \\
\hline $\begin{array}{l}\text { Pendidikan } \\
\text { Terakhir }\end{array}$ & 252 & 93,3 \\
$\begin{array}{l}\text { Pendidikan } \\
\text { Menengah }\end{array}$ & 18 & 6,7 \\
$\begin{array}{l}\text { Pendidikan } \\
\text { Rendah }\end{array}$ & 270 & 100 \\
\hline Total & 6 & 2,2 \\
\hline Pekerjaan & 55 & 20,4 \\
\hline Mahasiswa & & 19,3 \\
\hline $\begin{array}{l}\text { Pegawai Negri } \\
\text { Sipil }\end{array}$ & 52 & 4,0 \\
\hline Pegawai Swasta & 11 & 34,1 \\
\hline Pengajar & 92 & 20,0 \\
\hline Wiraswasta & 54 & 100 \\
\hline Buruh & 270 & \\
\hline Total & & \\
\hline
\end{tabular}

Berdasarkan tabel 1 dapat diperoleh informasi bahwa dengan kelompok umur 20-42 tahun sebesar 50,4 persen dan kelompok umur 43-66 tahun sebesar 49,6 persen. Distribusi responden berjenis kelamin laki-laki sebanyak 92,2 persen. Sedangkan distribusi responden perempuan sebanyak 7,8 persen. Distribusi responden berdasarkan riwayatpenyakit hipertensi yang memiliki riwayat penyakit hipertensi sebesar 82,2 persen dan yang tidak memiliki riwayat penyakit hipertensi sebesar 17,8 persen. Distribusi responden berdasarkan pendidikan terakhir paling banyak pada pendidikan menengah sebanyak 93,3 persen dan berdasarkan pekerjaan yang paling banyak adalah wiraswasta sebanyak 34,1 persen.

Berdasarkan hasil penelitian, distribusi kategori responden berdasarkan merokok yang dilihat dari kabiasaan merokok, lama merokok, jumlah batang rokok dan jenis rokok dapat dilihat pada tabel dibawah ini
Tabel 2

Distribusi Responden Berdasarkan Merokok (Merokok, Lama Merokok, Jumlah Batang Rokok dan Jenis Rokok)

\begin{tabular}{lcc}
\hline Merokok & $\mathrm{n}$ & $\%$ \\
\hline Merokok & & \\
\hline Ya & 221 & 81,9 \\
\hline Tidak & 49 & 19,1 \\
\hline Total & 270 & 100 \\
\hline Lama Merokok & \\
\hline$\geq 10$ Tahun & 196 & 88,7 \\
\hline$<10$ Tahun & 25 & 11,3 \\
\hline Total & 221 & 100 \\
\hline Jumlah Batang Rokok & & \\
\hline $11-20$ batang/hari & 191 & 86,0 \\
\hline 1-10 batang/hari & 30 & 14,0 \\
\hline Total & 221 & 100 \\
\hline Jenis Rokok & 144 & 65,2 \\
\hline Filter & 77 & 34,8 \\
\hline Non Filter & 221 & 100 \\
\hline Total & \\
\hline
\end{tabular}

Merokok dikategorikan menjadi merokok dan tidak merokok. Hasil penelitian pada tabel 2 menunjukkan responden dengan kabiasaan merokok sebanyak 81,9 persen dan responden dengan kebiasaan tidak merokok sebanyak 19,1 persen. Dari hasil jumlah respoden yang memiliki kebiasaan merokok yaitu sebanyak 221 orang diperoleh distribusi berdasarkan lama merokok yang dikategorikan menjadi $\geq$ 10 tahun sebanyak 88,7 persen dan $<10$ tahun sebanyak 11,3 persen. Berdasarkan jumlah batang rokok dikategorikan menjadi 1-10batang/hari sebanyak 14,0 persen dan 11-20 batang/hari sebanyak 86,0 persen dan distribusi berdasarkan jenis rokok dikategorikan menjadi filter sebanyak 65,2 persen dan non filter sebanyak 34,8 persen.

Berdasarkan hasil penelitian, distribusi kategori responden berdasarkan kejadian hipertensi dapat dilihat pada tabel dibawah ini: 
Tabel 3

Distribusi Kategori Responden Berdasarkan Kejadian Hipertensi

\begin{tabular}{lcc}
\hline Hipertensi & $\mathrm{N}$ & $\%$ \\
\hline Ya & 189 & 70 \\
Tidak & 81 & 30 \\
\hline Total & 270 & 100 \\
\hline
\end{tabular}

Kejadian hipertensi di kategorikan menjadi dua, yaitu hipertensi dan tidak hipertensi. Berdasarkan hasil penelitian menunjukkan sebagian besar responden mengalami hipertensi, yaitu sebesar 70 persen. Sedangkan responden yang tidak mengalami hipertensi sebesar 30 persen.

Tabel 4

Hasil Analisis Bivariat antara Merokok (Merokok, Lama Merokok, Jumlah Batang Rokok dan Jenis Rokok) dengan Kejadian Hipertensi

\begin{tabular}{|c|c|c|c|c|c|}
\hline \multirow[t]{2}{*}{ Merokok } & \multicolumn{3}{|c|}{ Kejadian Hipertensi } & $\begin{array}{c}\text { Tota } \\
1\end{array}$ & \multirow[t]{2}{*}{$\mathrm{p}$} \\
\hline & \multicolumn{4}{|c|}{ Hipertensi } & \\
\hline Merokok & & & & & \\
\hline $\mathrm{Ya}$ & 164 & $-74,2$ & 57 & $25, \varepsilon \underline{49} \quad \underline{100}$ & $\underline{0,002}$ \\
\hline Tidak & 25 & 51,0 & 24 & $49,0221,100$ & \\
\hline $\begin{array}{c}\text { Lama } \\
\text { Merokok }\end{array}$ & & & & & \\
\hline $\begin{array}{c}\quad \geq 10 \\
\text { Tahun }\end{array}$ & 153 & 61,9 & 60 & 24,3213100 & $\overline{0,036}$ \\
\hline $\begin{array}{l}\quad<10 \\
\text { Tahun }\end{array}$ & 27 & 10,9 & 7 & $2,8 \quad 34 \quad 100$ & \\
\hline $\begin{array}{l}\text { Jumlah } \\
\text { Batang } \\
\text { Rokok } \\
\end{array}$ & & & & & \\
\hline $\begin{array}{r}11-20 \\
\text { batang/hari }\end{array}$ & 146 & 65,8 & 18 & 8,1191100 & $\overline{0,034}$ \\
\hline $\begin{array}{c}1-10 \\
\text { batang/hari }\end{array}$ & 45 & 20,3 & 13 & $5,9 \quad 31 \quad 100$ & \\
\hline $\begin{array}{c}\text { Jenis } \\
\text { Rokok }\end{array}$ & & & & & \\
\hline Filter & 107 & $-74,3$ & 37 & $25,7 \underline{144} \underline{100}$ & 0,864 \\
\hline Non Filter & 56 & 72,7 & 21 & $27,377 \quad 100$ & \\
\hline
\end{tabular}

Berdasarkan tabel 4 hasil analisis bivariat diperoleh bahwa kebiasaan merokok $(\mathrm{p}=0,002)$, lama merokok ( $\mathrm{p}=0,036)$, dan jumlah batang rokok ( $\mathrm{p}=0,034)$ berhubungan secara signifikan dengan kejadian hipertensi yang ditentukan dengan nilai $\mathrm{p}<0,05$ artinya kabiasaan merokok, lama merokok dan jumlah batang rokok berpengaruh terhadap kejadian hipertensi di Kabupaten Pidie Jaya. Sedangkan jenis rokok $(\mathrm{p}=0,864)$ dimana nilai $p>0,05$ artinya jenis rokok tidak berpengaruh terhadap kejadian hipertensi di Kabupaten Pidie Jaya.

\section{B. Pembahasan}

Merokok merupakan salah satu gaya hidup dari responden yang memiliki resiko terhadap terjadinya hipertensi. Mayoritas responden memiliki kebiasaan merokok dana menderita hipertensi. Dari hasil bivariat diperoleh adanya hubungan antara kebiasaan merokok $(\mathrm{p}=0,002)$, lama merokok $(\mathrm{p}=0,036)$ dan jumlah batang rokok yang dikonsumsi $(\mathrm{p}=0,034)$ serta tidak adanya hubungan antara jenis rokok ( $\mathrm{p}=0,864)$ dengan kejadian hipertensi. dengan kejadian hipertensi. Mayoritas responden memiliki kebiasaan merokok $\geq 10$ tahun dengan jumlah 11-20 batang rokok per harinya dan memilih jenis rokok filter.

Penelitian ini sejalan dengan penelitian yang dilakukan oleh Firmansyah dimana menunjukan adanya hubungan merokok (p-value $=0,014)$ dengan tekanan darah pada pasien hipertensi di Puskesmas Pembina Palembang tahun 2016. Pada penelitian lainnya yang sejalan dilakukan oleh (Diana, 2018) diperoleh bahwa laki-laki dewasa pertengahan yang memiliki kebiasaan merokok sebagian besar mengalami hipertensi. Penelitian lainnya oleh (Gangwisch et al., 2006) yang menyebutkan bahwa kejadian hipertensi meningkat pada perokok yang berusia 35 tahun ke atas.

Dampak rokok memang akan terasa setelah 10-20 tahun pasca penggunaan. Rokok juga punya dose-response effect, artinya semakin muda usia mulaimerokok, semakin sulit untuk berhenti merokok, maka semakin lama seseorang 
akan memiliki kebiasaan merokok. Hal itu menyebabkan semakin besar pula risiko untuk menderita hipertensi. Kandungan nikotin dalam rokok non filter lebih besar dari rokok filter, sehingga risiko yang ditimbulkannya akan lebih besar. Jenis rokok filter dapat mengurangi masuknya nikotin ke dalam tubuh. Filter tersebut berfungsi sebagai penyaring asap rokok yang akan dihisap, sehingga nantinya tidak terlalu banyak bahan kimia yang akan masuk sampai ke paru-paru (Nurwidayanti \& Wahyuni, 2013).

Peningkatan tekanan darah pada perokok merupakan akibat dari rusaknya dinding pembuluh darah dan kekakuan pembuluh darah yang disebabkan oleh kandungan nikotin dan karbon monoksida dalam rokok. Perangsangan pada saraf simpatis oleh nikotin meningkatkan denyut jantung dan tekanan darah sistolik secara langsung dan selanjutnya meningkatkan pelepasan epineprin dan kerusakan pada lapisan endotel yang menyebabkan kekakuan pembuluh darah (Leone et al., 2015).

Merokok dapat meningkatkan risiko hipertensi. merokok mampu merusak jantung secara langsung dengan memicu vasokonstriksi dan mempercepat detak jantung yang akan menyebabkan jantung bekerja keras dan meningkatkan tekanan darah. Nikotin dalam rokok dapat mengikat oksigen dalam jantung dan merusak platelet, serta membentuk gumpalan darah. Nikotin juga dapat merusak pembuluh darah. Rusaknya pembuluh darah ini merupakan langkah pertama aterosklerosis. Apabila individu berhenti merokok maka risiko penyakit jantung koroner dapat menurun (Whitney \& Gabler, 2008)

Penelitian ini sejalan dengan penelitian yang dilakukan oleh (Srirawinda et al., 2018) menunjukan bahwa ada hubungan perilaku merokok dengan terjadinya hipertensi dengan nilai $(\mathrm{p}=0.012<0.05)$. Penelitian lainnya yang sejalan dilakukan oleoh (Yeo, 2020) bahwa jumlah rokok per hari mempengaruhi tekanan darah, dibuktikan dengan nilai signifikan sistolik $(\mathrm{p}=0,093)$. Hasil ini sejalan dengan penelitian (Setyanda et al., 2015) yang menunjukkan sangat besar pengaruh lama merokok terhadap kejadian hipertensi $(p=0,0017)$, artinya semakin lama memiliki kebiasaan merokok, maka semakin tinggi kemungkinan menderita hipertensi.

Berdasarkan hasil penelitian kebiasaan merokok tidak hanya sebagai suatu kebiasaan, tetapi sudah menjadi kebutuhan bagi pengunjung yang merokok di warung kopi. Bahkan responden merasakan seperti orang yang bingung jika tidak merokok. Perokok nerasakan ada yang kurang jika tidak merokok, karena rokok sudah menjadi kebutuhan yang harus dipenuhi. Beda halnya dengan pengunjung yang tidak merokok, mereka tidak setuju dan tidak mendukung kebiasaan merokok di kedai kopi dalam ruangan. Pengunjung warung kopi yang tidak merokok tersebut merasa terganggu dengan asap rokok pengunjung yang adadi kedai kopi. Akan tetapi, responden yang tidak merokok tersebut tidak memiliki hak untuk protes, karena kedai kopi dinilai sebagai tempat umum dan sudah menjadi hal biasa dan wajar jika merokok di kedai kopi.

Merokok atau tidak merokok dipahami sebagai pilihan dan semua yang ada dalam satu komunitas biasanya akan bersikap toleran. Pengunjung yang tidak merokok hanya berusaha menjaga jarak dan mengibaskan asap rokok yang mendekat ke arahnya. Ketika asap rokokdi dalam kedai sudah terlalu banyak dan membuatnya tidak tahan, barulahpengunjung yang tidak merokok keluar dari kedai kopi tanpa harus menegur atau 
menyinggung pengunjung yang merokok (Santoso et al., 2012).

Responden tetap merokok meskipun telah mengetahui dampak buruk dari rokok, karena merokok dianggap sebagai hal umum yang biasa dilakukan oleh berbagai kalangan di lingkungan sosialnya. Hal ini menunjukkaan bahwa lingkungan dan interaksi sosial memengaruhi perilaku individu untuk merokok, terutama pada komposisi masyarakat yang relatif homogen sepertidi Kabupaten Pidie Jaya.

Faktor gaya hidup masyarakat juga mulai menunjukkan perubahan seiring dengan perkembangan teknologi. Faktor pencetus penyebab hipertensi antara lain kurangnya istrirahat dan durasi tidur akibat kebiasaan minum kopi dan merokok, kemudian gaya hidup yang tidak sehat seperti kurangnya aktivitas fisik dengan lebih banyak duduk di warung kopi untuk minum kopi dan merokok serta kurangnya kesadaran masyarakat berolahraga menjadi beberapa faktor yang dapat menyebabkan timbulnya hipertensi. Pencegahan terhadap kebiasaan merokok yang dapat menyebabkan risiko hipertensi di Kabupaten Pidie Jaya dapat dilakukan dengan cara memberikan edukasikesehatan kepada masyarakat mengenai bahaya dan dampak merokok terhadap hipertensi seperti diantaranya mengadakan jadwal penyuluhan rutin, pemasangan poster mengenai bahaya merokok danminum kopi di beberapa titik warung kopi Kabupaten Pidie Jaya.

\section{Kesimpulan}

Berdasarkan penelitian yang dilakukan tentang pengaruh kebiasaan minum kopi dan merokok pada masyakarat di Kabupaten Pidie Jaya, maka disimpulkan karakteristik responden berdasarkan umur yaitu umur 20 43 tahun sebanyak 136 orang $(50,4 \%)$ dan 43 - 66 tahun sebanyak 134 orang $(49,6 \%)$, berdasarkan jenis kelamin dalam kejadian hipertensi dimana laki-laki sebanyak 249orang $(92,2 \%)$ dan perempuan sebanyak 21 orang $(7,7 \%)$, berdasarkan pendidikan terakhir dalam kejadian hipertensi sebanyak 252 orang $(92,2 \%)$ berpendidikan menengah

dan sebanyak 18 orang $(6,7 \%)$ berpendidikan rendah, berdasarkan riwayat hipertensi dalam kejadian hipertensi sebanyak 222 orang $(82,2)$ memiliki riwayat hipertensi dan sebanyak 48 orang $(17,8 \%)$ tidak memiliki riwayat hipertensi, berdasarkan pekerjaan dalam kejadian hipertensi paling banyak adalah sebanyak 92 orang $(34,1 \%)$ wiraswasta. Jumlah keseluruhan responden yang mengalami hipertensi sebanyak 159 orang $(58,9 \%)$ dari 270 responden. Terdapat hubungan antara merokok $(\mathrm{p}=0,002)$, lama merokok $(\mathrm{p}=0,036)$ dan jumlah batang rokok $(\mathrm{p}=0,034)$ namun tidak terdapat pengaruh jenis rokok $(\mathrm{p}=0,864)$ terhadap kejadian hipertensi di Kabupaten Pidie Jaya.

\section{BIBLIOGRAFI}

Diana, A. (2018). Pengaruh Label Peringatan Kesehatan Bergambar Dan Tulisan Di Kemasan Rokok Terhadap Intensitas Merokok Pada Siswa Smp.

Elvivin, E., Lestari, H., \& Ibrahim, K. (2016). Analisis Faktor Risiko Kebiasaan Mengkonsumsi Garam, Alkohol, Kebiasaan Merokok Dan Minum Kopi Terhadap Kejadian Dipertensi Pada Nelayan Suku Bajo Di Pulau Tasipi Kabupaten Muna Barat Tahun 2015. (Jurnal Ilmiah Mahasiswa Kesehatan Masyarakat), 1(3).

Firmansyah, A., Jahidin, A., \& Najamuddin, N. I. (2019). Efektivitas Penyuluhan Dengan Menggunakan Media Leaflet Dan Video Bahasa Daerah Terhadap Pengetahuan Bahaya Rokok Pada Remaja. Bina Generasi: Jurnal Kesehatan, 11(1), 80-86.

Gangwisch, J. E., Heymsfield, S. B., BodenAlbala, B., Buijs, R. M., Kreier, F., 
Pickering, T. G., Rundle, A. G., Zammit, G. K., \& Malaspina, D. (2006). Short Sleep Duration As A Risk Factor For Hypertension: Analyses Of The First National Health And Nutrition Examination Survey. Hypertension, 47(5), 833-839.

Leone, A., Spada, A., Battezzati, A.,Schiraldi, A., Aristil, J., \& Bertoli, S. (2015). Cultivation, Genetic, Ethnopharmacology, Phytochemistry And Pharmacology Of Moringa Oleifera Leaves: An Overview. International Journal Of Molecular Sciences, 16(6), 12791-12835.

Mainaki, R. (2019). HubunganKebersyukuran Dengan Kepuasan Kerja Pada Pegawai Dinas Kesehatan AcehUtara.

Martiani, A., \& Lelyana, R. (2012). Faktor Risiko Hipertensi Ditinjau Dari Kebiasaan Minum Kopi (Studi Kasus Di Wilayah Kerja Puskesmas Ungaran Pada Bulan Januari-Februari 2012). Diponegoro University.

Nurwidayanti, L., \& Wahyuni, C. U. (2013). Analisis Pengaruh Paparan Asap Rokok Di Rumah Pada Wanita Terhadap Kejadian Hipertensi. Jurnal Berkala Epidemiologi, 1(2), 244-253.

Organization, W. H. (2018). Who Expert Consultation On Rabies: Third Report (Vol. 1012). World Health Organization.

Pamaila, S. R. (2019). Hubungan Kualitas Lingkungan Fisik Rumah Dan Perilaku Kesehatan Dengan Kejadian Tb Paru Bta (+) Di 10 Desa Wilayah Kerja Uptd Puskesmas Meuraxa Kota Banda Aceh Tahun 2019.

Ri, K. (2016). Kementerian Kesehatan Republik Indonesia. 2018. Pedoman Umum Gizi Seimbang. Jakarta (Id): Direktorat Jenderal Bina Kesehatan Masyarakat.

Santoso, A., England, M. H., \& Cai, W.
(2012). Impact Of Indo-PacificFeedback Interactions On Enso Dynamics Diagnosed Using Ensemble Climate Simulations. Journal Of Climate, 25(21), 7743-7763.

Setyanda, Y. O. G., Sulastri, D., \& Lestari, Y. (2015). Hubungan Merokok Dengan Kejadian Hipertensi Pada Laki-Laki Usia 35-65 Tahun Di Kota Padang. Jurnal Kesehatan Andalas, 4(2).

Srirawinda, S., Kunoli, F. J., \& Baculu, E. P. H. (2018). Hubungan Perilaku Merokok Dan Pola Konsumsi Kopi Dengan Terjadinya Hipertensi Di Puskesmas Momunu Kabupaten Buol. Jurnal Kolaboratif Sains, 1(1).

Whitney, K. D., \& Gabler, C. A. (2008). Rapid Evolution In Introduced Species, 'Invasive Traits' And Recipient Communities: Challenges For Predicting Invasive Potential. Diversity And Distributions, 14(4), 569-580.

Yeo, S. L. (2020). The Scope And Limits Of Debunking Arguments In Ethics. The Australian National University (Australia). 


\section{Copyright holder :}

Nuriani, Kintoko Rochadi dan Fazidah Aguslina Siregar (2021)

First publication right :

Jurnal Health Sains

This article is licensed under:

(c) (7) (2) 